\section{Prehistory of Southern Central America}

\author{
Alexander Geurds \\ Institute of Archaeology, University of Oxford, \\ Oxford, Oxfordshire, UK \\ Faculty of Archaeology, Leiden University, \\ Leiden, The Netherlands
}

\section{State of Knowledge and Current Debates}

\section{Introduction}

The definition of southern Central America used here includes the territory of Panama, Costa Rica, Nicaragua, Honduras, and (eastern) El Salvador while making brief mention of Colombia. Central America typically also includes Guatemala, Belize, and the western part of El Salvador, but the archaeology of these territories is tied more strongly to discussions on the Mesoamerican culture area. The prehistory of southern Central America comprises the Terminal Pleistocene and the Holocene period, from initial peopling of the region up to the period of European colonization in the first half of the sixteenth century. With some frequency, the region is defined as a corridor for human, animal, and plant dispersal. For the earliest Paleoindian period (11500-10,000 BP), the preceramic period (10000-4000 BP), as well as more recent prehistoric times, southern Central America is considered a key area for understanding human mobility, environmental adaptation, and long-distance exchange in the Americas and indeed from a global archaeology perspective.

With the exception of multidisciplinary work in Panama between archaeology and paleoecology, the Paleoindian period is lacking robust chronological control throughout much of the region, the principal exception being central Panama. The long process of plant domestication was introduced, altering the overall vegetation, and around 4000 BP horticultural and agricultural practices were beginning to define the landscapes of both Pacific and Caribbean Central America. During the first decade of the sixteenth century, Spanish colonizers arrived on the Caribbean coast of Panama, going across the continental divide to reach the Pacific and quickly moving northward via the Pacific coast, thereby abruptly ending the prehistoric developmental trajectory, although some indications point to the effective continuation of indigenous lifeways over various decades before the impact of Spanish colonization becomes visible archaeologically. The first half of the sixteenth century left indigenous societies decimated in size and forced surviving groups to seek refuge in difficult to penetrate interior mountainous and tropical forest regions.

The region lacks a singular unifying macroregional narrative, partly due to an overall geography that is varied in nature, caused by a complex geological history including volcanism and active tectonic conditions on the Pacific coast. On the whole, geographical contrasts are somewhat more pronounced in Honduras, Nicaragua, and northern 
Costa Rica than is the case for central and eastern Panama. Most poignantly, southern Central America is described as a mixture of isthmian and insular forms of landscapes (Cooke 2005).

The prehistory of southern Central America is marked by a history of definitional debates on external and internal spatial boundaries, predominantly in relation to its position to Mesoamerica and parts of northwestern South America. Until recently, the overall area nomenclature was subject to change, with earlier literature invoking area concepts such as "Lower Central America" and "Intermediate Area." Apart from some of these area container concepts receiving critique for their essentially negative definition (Sheets 1992), others only outline those parts of Central America not deemed to show Mesoamerican traits, such as the "Chibchan tradition" (Kirchhoff 1943) or the "Isthmo-Colombian Area" (Hoopes and Fonseca 2003). It's fair to say that this debate is not concluded, with current interpretive emphases shifting to socially informed network perspectives over culture areal discussions. For this entry, the definition of southern Central America is principally geographical and in acknowledgment of the heuristically complex relation to the Mesoamerican culture area. It includes brief references to parts of Mesoamerica, as well as encompassing those societies displaying forms of relatedness further south, into northwestern Colombia, extending into western Venezuela.

\section{Area Definition}

Spatial boundaries recognized in archaeology are always conditioned by time and tend to be uninformative for archaeological reconstructions of prehistoric life, making their definition inherently problematic. Similar problems are encountered in the choice of terms for these regions, all of which carry their own set of implied comparative assumptions. Lastly, when southern Central American subareas are defined, then it is generally only for materials and cultural patterns from $500 \mathrm{BC}$ and later, with an emphasis from $\mathrm{AD}$ 600 to 1500 , when sociopolitical formations develop and material culture further diversifies in southern Central America. Despite Spanish reports discussing political landscapes in considerable detail, they are difficult to observe archaeologically in southern Central America for most periods, including the last centuries before the Spanish colonization, with exceptions in central Panama and Caribbean Costa Rica.

The northwestern edges of southern Central America are defined by periods of frequent interaction with the southern extension of Mesoamerica. This includes the Maya region, marked by the linguistic spread of Mayan languages into western Honduras and El Salvador, in combination with the presence of stone carved hieroglyphs from about $\mathrm{AD}$ 250. This zone is geographically defined to run along the central valleys of Honduras, geologically formed by the Comayagua graben, trending north-south through the country. On the Pacific side, in eastern El Salvador, the regional dynamics are more complex to the point of becoming unclear. Eastern El Salvador, covering about one-third of the national territory, is formed by the course of the Lempa River (Longyear 1966), and this region, together with the adjacent Gulf of Fonseca, presents varied cultural characteristics through time, featuring both localized and Mesoamerican elements. More recent discussions frame this lack of clear patterning as indications of periodic links across cultural boundaries (Sampeck 2014). Following the Pacific coast further south, Greater Nicoya includes the Pacific regions of Nicaragua and the Nicoya peninsula of Costa Rica and was defined originally as a cultural subarea of Mesoamerica, emerging around AD 800, although discussions on this regional perspective are now relying less on historical references to human migratory movements and pushing for more critical and localized archaeological understandings of Greater Nicoya (McCafferty et al. 2012). Greater Nicoya is more clearly supported by archaeological evidence in Pacific Nicaragua and Nicoya, than it currently is for the wider tri-national area around the Gulf of Fonseca.

The southern extremity of southern Central America is particularly challenging to address, as numerous historically deep linguistic and genetic ties exist with parts of contemporary northwest and Caribbean Colombia, and interaction 
networks were likely frequent and long term, especially from $\mathrm{AD} 0$ onward. A strong ecological continuity between eastern Panama and the Colombian Chocó region as well as around the Gulf of Urabá into the Caribbean plains further strengthens such a hypothesis. Cultural exchanges with parts of Colombia are amplified further by a comparable semiotic corpus materialized in classes of objects, prominently including decorated pottery, metal objects, ground stone sculpture, particular forms of green stone pendants, as well as practices of shell carving. Such exchange and transfer of ideas and practices eventually connected the most northerly stretches of the Andes, the Sierra Nevada de Santa Marta, to parts of Panama and Costa Rica, even though objects chemically sourced to have traversed such distances remain scarce as a result of the lack of analysis. Beyond this, comparisons have also been drawn between the sculptural practices of southern Central American and those of the Cauca Valley in southern Colombia. In short, there is no agreement on where to draw a southern boundary for the prehistory of southern Central America, even if only for heuristic purpose, but it is likely that this boundary not to be sought in Panama but in fact somewhere in northwest South America.

Overall, southern Central America is defined by starkly contrasting geographies, consisting of a combination of tropical highlands and lowlands, each having their own climate and vegetative characteristics (Coates and Obando 1996). Trade winds pushing weather systems into eastern parts of southern Central America influence this geography, leading to more temperate zones on the Pacific side and at times featuring a transitional central highland zone as a third major geographical component. As such the geographical contrast extends to form quite divergent climates on the Caribbean and Pacific coast; the former featuring moist rainforests and the latter defined by drier conditions and a less pronounced hydrology. In Nicaragua, this contrast is influenced by the two large freshwater lakes, geologically formed by the Nicaraguan depression. The larger of the two, Lake Cocibolca (or Lake Nicaragua), drains into the Caribbean Sea by way of the San Juan River, thereby forming the only straightforward connection between Pacific Nicaragua and the Caribbean. In the low-lying grasslands where the lakes are situated, a front arc of active stratovolcanoes is a further main geographical feature. With numerous historically recorded eruptions, this volcanism played a crucial role in later prehistoric periods as well, resulting in abrupt shifts in, for example, settlement pattern and pottery technology. The presence of the two freshwater lakes and the fertile soils generated by the volcanic ash deposits presented favorable conditions in Pacific Nicaragua for early prehistoric settlement.

The eastern region of Honduras, extending northeast of the capital Tegucigalpa toward the Caribbean coastline, comprises an expansive zone of tropical forest, the largest surviving continuous one in Central America today. Rugged terrain and high precipitation make for a challenging environment for archaeological research, and accordingly regional data resolution is still unsatisfactory. The eastern portion of Honduras, crossing the Nicaragua and Honduras border along the Caribbean Sea, is referred to as La Mosquitia. This region of grassy savannas, pine forests, marshes, and tidal lagoons is ecologically similar to the Caribbean coastline of Nicaragua. The extensive river deltas and shallow offshore waters that mark this Miskito or Mosquito Coast in Nicaragua are at the root of the isolation these coastal regions have experienced, being largely cut off from the interior regions of Nicaragua and its Pacific coast. In central regions of Nicaragua, there are some archaeological indications of periodic exploitation of Caribbean maritime resources.

The remoteness of the Nicaraguan Caribbean was a likely determinant of regional interaction in prehistory, as it was during Colonial times and in part still is today. These Caribbean coasts run south to eastern Panama, cut by the estuaries of a few major rivers such as the San Juan and the Reventazón River in Costa Rica. Horticultural activities in the Caribbean probably took the form of small gardens near houses, planted with species with an array of purposes. Cultivated flora included plants known for medicinal qualities and those suitable for construction purposes. There are 
also early historical Spanish references to plantations of peach-palm trees. Finally, in southern Costa Rica, the Caribbean coast is defined by lowland plains where the terrains narrow, giving way to the highlands of the Cordillera de Talamanca that approach the Caribbean coast toward the border with Panama. The Caribbean regions of eastern Honduras, Nicaragua, and Costa Rica are often compared and presented in a joint analysis, sometimes highlighting their "wedged" position alongside the Pacific and central regions, but considerable linguistic and style differences were also present.

Archaeological studies generally focus on sites or natural units of analysis in either the Caribbean lowlands, the Pacific coast, or central valleys or plateaus at somewhat higher elevations. The geography generally facilitates human mobility parallel to the coastlines, and specific cultural and linguistic clustering from AD 600 to 800 onward seems to be loosely correlated to such geographies. That said, the cultural links in the geographically diverse south of Costa Rica and west of Panama provide a counterexample. One element that is a prominent feature in Central America is the range of active volcanoes running from Guatemala all the way into western Panama, interrupted only by the mostly metamorphic Cordillera de Talamanca. Beyond the numerous prehistoric and recorded historic eruptions, volcanism, and the tectonics underlying their existence, has given rise to highlands, lakes, and extensive lands covered by ash lenses, creating fertile grounds along the Pacific coasts. Alongside the effects on prehistoric subsistence strategies (Sheets and McKee 1994), the highly visible presence of volcanoes is also discussed in terms of how they are rendered in prehistoric indigenous interpretive landscapes.

Southern Costa Rica and western Panama include the Osa Peninsula, and it encompasses the Diquís valley as well as the provinces of Chiriquí and Bocas del Toro. Many river valleys and plains characterize this region, creating a fragmented topography. This nowadays bi-national subarea of Greater Chiriquí is generally treated as a single archaeological unit of analysis, given the already mentioned significant overlap in prehistoric practices and styles visible between them. The Cordillera de Talamanca mountain range separates this region from the Caribbean coast, but there are archaeological indications of comparable cultural developments between the Pacific and Caribbean. Further east, the central provinces of Panama are marked by a combination of stretches of savannas as well as tropical forest zones, a narrow central mountain range of reaching to some 200 meters above sea level, broad coastal bays, and the central lowland zone of the Panama Canal. The distance between Caribbean Sea and Pacific is at times as little as 70 kilometers here. Various rivers discharge into the Pacific Ocean here, creating wide deltas, and in the Gulf of Panama, a number of islands are found that potentially played a role in shell trade along the Pacific littoral. Interestingly, islands are otherwise fairly scarce along the coasts of Central America. Of note are those in the Gulf of Fonseca, in the Gulf of Nicoya, a small spread off the Pacific coast of Chiriquí, the San Blas Islands of Caribbean Panama, and the Pearl Islands of the Pacific Panama. When archaeologically investigated, all exhibited traces of prehistoric habitation or exploitation of maritime resources. This nearshore prehistoric activity is a defining feature for the prehistory of southern Central America, as it features a relatively high coastline-to-land area ratio.

Finally, the eastern third of Panama encompasses the Darien, a region about which systematic regional archaeological knowledge is still very limited, apart from a handful of studies and recent paleoecological investigations. It is a densely forested region, enveloping the entire land area from the Caribbean to the Pacific coast, with hills of modest height near the Caribbean coast, creating wider plains on the Pacific than elsewhere in Panama and covered with subtropical forests. This vegetation is, as mentioned earlier, comparable to the Chocó region environment across the Colombian border. Similar to other examples in southern Central America, here also, contemporary nation state borders complicate regional analysis. 


\section{Scholarly Background}

Through a combination of historical circumstances and an aesthetically pleasing material culture, the beginnings of systematic archaeology in southern Central America coincide with some of the earliest archaeological studies in the Americas. Historical reasons for this were both US and European economic exploitation in southern Central America through banana and coffee plantations alongside the extraction of various precious metals, further amplified by the establishment of railroads across difficult terrain and repeated efforts to establish a transcontinental canal (initially proposed for Nicaragua, and later for central Panama). These nineteenth- and early twentieth-century conditions resulted in a substantial presence of foreign cartographers, engineers, and travelers, observing on the archaeological remains they encountered. During the first three decades of the twentieth century, a small number of studies were undertaken to explore the indigenous prehistory based on museum collections and field research aimed at assembling archaeological, linguistic, and ethnographic observations. In terms of field archaeology, Carl Hartman's early work on a number of monumental sites in Caribbean and Pacific Costa Rica stands out for its meticulous approach and reporting in this early period of research (e.g., Hartman 1901, 1907). Ironically, these early studies were followed by a long period of relative paucity of advancements in the understanding of prehistoric developments, while neighboring regions, prominently Mesoamerica, saw a stark increase in the volume of field projects and overall academic study.

During the second half of the twentieth century, national archaeologies gradually developed, though not necessarily in a comparable way throughout southern Central America. In this same period, from the 1950s onward, a number of archaeological studies followed by scholars based in the USA and Europe. Central to this renewed investigative focus were the argued links between parts of Mesoamerica and coastal South America. Such links, fundamental under the proposed notion of "Nuclear America" (Willey 1955), naturally called for viewing southern Central America as a developmental "axis" between parts of Mexico and its links to the central Andes of Ecuador and Peru. Consequently, a number of archaeological surveying and test excavations were set up along the Pacific coast (overview in Healy 1980). One of the results of research in this period is the observation that earlier indigenous societies on the Pacific coast of Nicaragua and northwest Costa Rica showed Central American characteristics, whereas during later periods, a Mesoamerican influence becomes noticeable. Primarily, these projects obtained a set of markers for macroregional spatiotemporal control, in many cases the first of its kind in the respective parts of southern Central America.

Later work, during the later 1960s and 1970s, continued to build on existing chronological sequences, expanding on the knowledge of ceramic styles and also outlining regional subsistence strategies and settlement patterns in both the Pacific and Caribbean sides of southern Central America. During this period, the first synthetic publications began to appear, some contained in handbooks, or as monographs (Baudez 1970; Stone 1972), others as standalone articles, such as Olga Linares's still remarkably fresh views (Linares 1979). Studies also sought to address the question of the nature of crop domestication and dispersal and the transfer of particular technologies such as metallurgy across the Americas.

By the 1980s, archaeological research was beginning to grow more substantially, but this was per Central American country highly dependent on political development, causing, for example, a marked difference in research activity between the stable democracy of Costa Rica and the civil war-torn conditions of Nicaragua and El Salvador. In Panama, the establishment of the Smithsonian Tropical Research Institute in 1966 (with historical roots in the Panama Canal project) provided a major push in studies on humanenvironment relations, paleoecological reconstructions, and the initial period of human settlement of southern Central America. Since then, the volume of archaeological work has steadily increased, helped by the presence of several local institutes and a combination of both US or European field research by dedicated 
archaeologists and their students as well as multiple edited volumes published between the 1980s and now.

\section{Human Adaptation and Mobility}

A returning theme of interest for research is the role of human mobility in the prehistory of southern Central America. Depending on the period under discussion, tropes such as colonization, dispersal, and migration are introduced in the different national archaeologies. Such archaeological discussions receive additional input from genetics, linguistics, and observations found in early Colonial period historical documents. While several decisive occurrences mark the long period from 11,500 BP onward, the events around AD 300-600 (cf. Hoopes 2005) impacted the cultural landscape of the southern Central America, and the social dynamics that have underlain such changes have received the bulk of archaeological study. The most important sources of information that support such migrations are linguistic and ethnohistoric in nature, with supporting indications coming from changes in the decorative style of polychrome pottery. Archaeological research focused on ethnic identification, and the direct sourcing of materials involved in such human mobility has, however, produced mixed results, highlighting the complex relation between historical writings (based on indigenous oral history) and the traces of human action as recovered archaeologically.

A second focus on human mobility argues for back migrations (after initial dispersal) from northwest South America into Panama, Costa Rica, and further along the Caribbean side of Central America, including the Honduran Mosquitia region. This argument gives rise to the mentioned IsthmoColombian or Chibchan archaeological area thesis (Fonseca 1994; Hoopes and Fonseca 2003), and its formulation resides principally on contact deduced from shared material culture, motifs, and technology and later also combined with common linguistic roots and mitochondrial DNA studies. This thesis rests in part on certain iconographic foci depicted on objects fashioned out of gold, ceramics, ground stone, and lustrous jade-like polished stone and including a regional preference to depict double spirals, crocodilian motifs, and humans in a state of transformation. The ample archaeological relations to parts of South America help to illustrate the definitional complexity of an archaeology of southern Central America.

\section{Paleoindian Period}

The record for the earliest evidence of human activity in southern Central America does not allow for a regional reconstruction of sufficient detail, keeping in mind that securely dated South American Pleistocene sites such as Monte Verde have yielded dates of 14,500 BP with even earlier dates still possible (Dillehay et al. 2015). In general, the peopling of the Americas remains a highly debated research focus, with different views on initial points in time, routes, and chronological development. For southern Central America, the most substantial data set able to contribute to this debate come from Panama, where the earliest traces of human-induced vegetation changes and documented artifacts date to approximately 11,500 BP (Cooke et al. 2013). These would have been small and highly mobile hunter-gatherer groups, occupying rock-shelters for habitation and roaming between coastal and more highland regions, hunting for large fauna. Water locked in land ice resulted in lowered sea levels by as much as 100 meters relative to current levels before the end of the Late Glacial Maximum (13,000 BP). Significant areas of land were left exposed, greatly changing the coastlines of southern Central America. One example of this would be the entire Bay of Panama, which was a plain covered with deciduous vegetation. Climatological conditions were also different from later Holocene averages (which stabilized to current values around $8000 \mathrm{BP}$ ), with mean temperature dropping several degrees centigrade, and precipitation levels also lower compared to today. Toward 10,000 BP, the dwindling numbers of large game, combined with the warming trend, probably gave rise to a focus on biota consisting of smaller animals and a greater diversity of edible plants in the diet.

\section{Preceramic Period}

At the onset of the Holocene around 10,500 to $10,000 \mathrm{BP}$, the technologies used for fashioning 
lithic tools are still firmly based on flaking in order to produce for example unfluted and fluted projectiles, but this period now also sees the emergence of ground stone tools, indicative of the increased processing of plants. Outside of Panama, convincing data from other southern Central American regions remains very spotty, although it can be assumed with some confidence that small groups accessed all geographical regions of Central America right from the outset of the Holocene, including the Caribbean lowlands and highland mountain ranges. Thick volcanic deposits along the Pacific coast, obscuring preceramic sites, likely play a role in this as well. In the case of central Panama, groups appear to become more selective in choosing locations for habitation, and there is evidence for clearing of forests by burning. Further insights gained primarily from coring lakebeds point to the first indications of root crop domestication between 9000 and 8000 BP (Piperno et al. 1991). The intensity of human activity further increases in central Panama toward $7000 \mathrm{BP}$, with more extensive evidence for forest clearings, accompanied by the occasional traces of habitation in rock-shelters. Also, maize appears for the first time in the paleoecological microfossil record around $7600 \mathrm{BP}$, and it is likely that the adoption of maize cultivation is causally related to the observed further decrease in primary forest. Domesticated in the southwest Mexican state of Guerrero around 10,000 BP, maize dispersed rapidly through southern Central America and into South America, but how it did so remains another widely debated and researched topic. Reliable data for following this dispersal trajectory is found in central Panama and Costa Rica, with little excavation data coming from elsewhere in southern Central America. Similar to later data from parts of Caribbean regions, palm nuts and other types of fruit-bearing trees also form part of the diet during this period.

\section{First Pottery}

There is convincing evidence for early pottery outside of southern Central America, from the San Jacinto site in the foothills of northwest Colombia (5900-5300 cal BP), but the earliest forms of pottery in Central America are presumed to be independent inventions (Hoopes 1994). Such pottery may have initially served for storage purposes alongside natural gourd containers or possibly also for competitive feasting (Hoopes 1995). Alongside pottery, the first traces of refuse piles, including shell mounds, are known from Pacific coastal bay areas in central Panama, and traces of early domestic structures are documented at the Tronadora Vieja site around the Arenal Volcano in Costa Rica around 3800 BP.

Around $5500 \mathrm{cal} \mathrm{BP}$, the first traces for pottery manufacture appear in the archaeological record of southern Central America. This data comes from coastal and inland sites in Panama, including Monagrillo (5470-3250 cal BP). Somewhat later are ceramic deposits from northwest Costa Rica (4000-2500 cal BP). This Tronadora-style pottery from northwest Costa Rica, though rare in occurrence, may be indicative of materials found along the wider Pacific coast further north toward Nicaragua and south toward western Panama and into the Caribbean lowlands. The developed technology of this pottery, however, suggests even earlier, as yet unidentified, forms (Corrales 2000).

Though based on a fragmentary data set, the last two millennia $\mathrm{BC}$ show a pattern of rising human impact on the environment with coring data showing further decreasing primary forest taxa and an increased reliance on domesticates such as maize, manioc, squash, and sweet potato. Simple fishing in tidal pools is beginning to expand to more advanced shoreline fishing technology, documented in the Parita area at the Bay of Panama, involving nets and possibly using simple canoes or other forms of flotation. For southern Central America in general, it can be assumed that the adoption of a more agricultural lifestyle, including the production of pottery, took place over a long timeframe, with groups living in tropical montane regions continuing a foraging subsistence strategy while those in seasonally drier environments relying more on cultivated staple crops. From around 500 BC onward, the archaeological record becomes far more varied across southern Central America, with production and exchange in material culture increasing and the first patterns in settlement location becoming apparent. It is also this period (500 BC-AD 1520), upon which the majority of past and current 
archaeological investigations are focused. Such investigations invariably are contained to one country, as reflected in the country discussions below.

\section{Honduras}

With Maya societies living in the extreme western regions of Honduras, the main central, northern, and eastern parts of the country reveal a complex zone of communities interacting to various levels from approximately $1000 \mathrm{BC}$ onward. Most of these early sites are situated in various Honduran intermontane valleys, such as Ulúa, Lake Yojóa, $\mathrm{Naco}$, and Comayagua. Already at this relatively early stage, communities were taking part in interregional interaction networks reaching into Mesoamerica, as evidenced by pottery made locally but stylistically reminiscent of Olmec objects. This is perhaps unsurprising given the macroregional importance of the regionally unique source of jadeite in the Motagua Valley of Guatemala and the role of cacao as a product from the tropical regions of Honduras, sought after in societies far beyond local cultural horizons (Healy 1984). During this first half of the last millennium BC, we also see the first evidence for mound and raised platform construction (Joyce 2004).

Following these early expressions of monumentality is the advent of the hallmark Usulután ceramic style, spreading through much of Honduras and El Salvador from the latter half of the last millennium BC and in use up to roughly AD 400. Due to its distinctive orange and cream appearance, combined with resist decoration, and a specific range of rather fine pastes, Usulután ceramics are the most highly diagnostic ceramic ware in Honduras during this period. While for a long time considered a trade ware, more recent neutron activation and petrographic studies are changing this view, pointing instead to various local production points. Usulután wares are documented in most of the sites excavated in the mentioned Honduran valleys, with the exception of the northeastern region where it is noticeably absent. The advent of Usulután is accompanied by increases in site density and overall contacts between and beyond these regions.
During the centuries after this, up to about AD 1000 , mound and platform construction continues to intensify, introducing ball courts (typical for Mesoamerica) into both central and eastern Honduras, expanding ceremonial mound-lined plazas and showing signs of possible site ranking in two or three levels. New earthworks are added to those at previously occupied sites, not infrequently obscuring earlier constructions. Apart from this steady intensification of building activity, this period is signaled archaeologically by the appearance of the so-called Ulúa-Yojoa polychrome wares and interaction with the major Maya settlement of Copán. The Ulúa-Yojoa polychromes, a broad category of decorated pottery, including flat-bottomed cylindrical vessels, has a long history in the archaeology of Honduras and is documented stylistically in excavations in Nicaragua, El Salvador, and even Guatemala (Joyce 2017). Alongside this polychrome group, the second defining object class is a small but distinctive corpus of cylindrical vessels sculpted in marble, produced in limited numbers at a specific workshop at the center of Travesía in the Ulúa Valley, and appearing in sites in the Maya lowlands and Pacific Nicaragua. Both the increase in monumental architecture and the evidence for craft specialization may help in arguing the stability of the communities responsible for this activity. While authors have argued for the emergence of incipient chiefdoms in his period, there is little evidence, for example, from funerary settings, for any form of chiefly elite, leaving open the alternative explanation by means of heterarchical cooperative structures.

The period from AD 1000 onward shows a decrease in building activity in many of the Honduran valleys. A straightforward link to the population decline is observed at Copán a century or two prior to this period, invoked by the so-called Maya Collapse. Although the intensity and velocity of this decline is the topic of ongoing debate, it is likely that any mayor change would have entailed consequences for other Honduran regions. Although there is a decrease in the previously seen rise in sites and possibly also in population density, it is not a period of sharp shifts in settlement patterns. Numerous sites continue to be 
occupied after AD 900, including Las Vegas and Los Naranjos, and Copán itself continues to show some activity. The Naco Valley is one of the best studied areas for this period. Sites there are known to have played a central role in coastal trade networks reaching from the coasts of Honduras, across the Yucatán peninsula, to the Gulf of Mexico. Recent research in the Naco Valley sites highlight the negotiation of authority and local political hierarchies, using networks of exchange to bring in exotic materials (Schortman and Urban 2011). Interaction networks to other parts of southern Central America are also evidenced by moderate amounts of Greater Nicoya whiteslipped polychrome decorated pottery at sites in central Honduras as well as elements of styles from Honduras, Nicaragua, and Costa Rica. Contacts toward Mesoamerican subregions are indicated by the presence of small amounts of copper objects and a few instances of the trade ware ceramic-type Tohil Plumbate from El Salvador at Copán and on the Bay Islands off the Caribbean coast.

In the northeastern region, site surveying and mapping has produced evidence for substantial habitation after AD 1000. Numerous sites, some of which in defensible locations, show considerable elongated mound-plaza architecture, exceeding sites from previous periods in size and planning. Overall, these sites still do not adhere to a self-evident orthogonal layout, instead combining architectural elements depending on local topography, drainage, and vantage points, but the increase in overall planning is evident. In terms of material culture, there is a noteworthy orientation toward the Caribbean lowlands of Nicaragua and Costa Rica, with a tradition emerging of sculpting stone monoliths and fashioning elaborate milling stones. Most recently, an investigation into coastal sites was initiated to better understand existing local typologies and regional relations. Despite this work, and its being one of the largest regions in Honduras, the northeast remains one of the archaeologically least-known parts of southern Central America.

The archaeology of Honduras reveals connections of stylistic forms and materials to Central American regions further south. Furthermore, there is a relation of selective exchange through the network node of Copán and beyond this to trade routes from more central parts of Mesoamerica. From the last millennium BC onward, and continuing into the last centuries before the Spanish Conquest, such networks, while subject to periodic change, remained a constant feature, evidenced primarily through the trade in rare commodities. Simultaneously, site layouts and structures, and more regional level settlement patterns, seem to have maintained a certain level of resilience in their trajectories within the multiple valleys that mark the cultural landscape of Honduras. While major macroregional changes like the Maya Collapse during the ninth century AD were certainly not without their effect, complete ruptures of past cultural patterns and connections seem to not have occurred. In fact, northeast Honduras saw an increase in activity and the proliferation of material practices, possibly intensifying ties with Caribbean regions further south.

\section{The Gulf of Fonseca and Eastern El Salvador}

The Gulf of Fonseca is shared by eastern El Salvador, southern Honduras, and northwest Nicaragua. This is one of the most particular coastal features of southern Central America, marked by extensive mangrove forests and tidal flats, alongside delta-like mud plains. A number of islands dot the Gulf, and numerous rivers discharge their water coming from the valleys of central Honduras. The Gulf is a product of active tectonics, leading to faulting and volcanism occurring along the wider Pacific coastline. There is considerable uncertainty about the archaeology of this region, even though it is likely to have featured substantially as an area of fishing in prehistoric times. In macroregional perspectives, the Gulf is typically seen as a waypoint in the networks of exchange that are argued to have existed along the Pacific coast. For AD 800 and later, it forms an as yet unresolved nexus between more southern Central American-oriented communities and those more strongly resembling Mesoamerican cultural patterns. Notwithstanding this regional uncertainty, substantial archaeological work done on the Gulf region is lacking, with past research documenting several small settlements 
and salt-making sites on the Honduras side of the coast with human activity going back to $\mathrm{AD}$ 300 and continuing until the arrival of the Spanish (Baudez 1976). Despite this dearth of research, there are indications that the Gulf filled an important role in interzonal economic exchange between local coastal communities and those further toward the interior in the surrounding valleys. Such "vertical" interaction merits more scholarly attention, as southern Central America overall is a region with an above-average amount of coastal zones relative to inland surfaces.

Starting west of the gulf and naturally bounded by the Lempa River, eastern El Salvador demonstrates connections to the material culture of southern Central America by means of contemporaneous presence of certain ceramic types or trade wares during the last millennium BC and the first millennium AD. Especially widely recorded Usulután-style pottery appears in significant quantity at eastern El Salvadoran sites such as Chalchuapa and Usulután (the site after which the ware is named). Between AD 1000 and 1200 , the presence of Papagayo Polychrome pottery, having its origin in Pacific Nicaragua (see below), is indicative of connections of eastern $\mathrm{El}$ Salvador with more southern regions. In the regional perspective, the archaeology of eastern El Salvador is a crucial connection in evaluating the changes in relations between southern Central America and more northern regions, such as the Maya lowlands, the Gulf Coast of Mexico, and southern parts of Mexico. The more prolonged studied site Quelepa provides strong evidence for such diachronic shifts in macroregional connections (Andrews 1976), which, perhaps remarkably, appear to exclude the Maya center of Copán.

\section{Pacific Nicaragua and Northwest Costa Rica}

Around $1000 \mathrm{BC}$, the earliest traces of habitation are documented in parts of Pacific Nicaragua and northwest Costa Rica in the form of shell middens and hearths associated with diagnostic incised and striated monochrome and bichrome ceramic wares. Funerary practices are varied in form, including both secondary urn burials and primary extended interments, the latter often with three- or four-legged grinding stones or stools present, on which the deceased is sometimes placed. Further grave goods can include polished stones made of jadeite or visually similar materials and ground stone mace heads. While archaeological data remains scarce for this period, it is accepted that it continues to up to around AD 500, when polychrome pottery types appear and there is a subsistence shift to include exploitation of maritime resources. From AD 800 onward, the material culture in Pacific Nicaragua shows strong resemblances to that found in northwest Costa Rica (principally the Nicoya Peninsula), and this similarity in pottery is the background for the notion of the Greater Nicoya archaeological region. As with most other regions of southern Central America, its boundaries are only approximately defined, but it is generally understood to envelop the shores of both Lake Xolotlán and Lake Cocibolca and the foothills of central Nicaragua, as well as reaching up to the Gulf of Fonseca. For northwest Costa Rica, the Nicoya peninsula and the Tempisque River Valley are the primary features, with the Tilarán mountain range forming a natural southeastern extremity.

In contrast to the other regions discussed here, Greater Nicoya was originally defined to denote an extension of the Mesoamerican culture area (Lange 1984). This initial proposal was motivated by ethnohistoric similarity to Mesoamerica (Kirchhoff 1943), later evidenced by a combination of regionally shared changes in pottery, including motifs and symbols appearing on polychrome ceramics in the region, alongside developments in lithic technology, and ethnohistoric references to migration of Mesoamerican language speakers into the region sometime around AD 800 (Norweb 1964). By now, Greater Nicoya is recognized as a region with strong local cultural dynamics, even when exhibiting a relatively high amount of identical ceramic types when compared with surrounding archaeological regions of Central America (Healy 1980). Compared to other regions of southern Central America, several parts of Pacific Nicaragua and northwest Costa Rica are at least to some degree known archaeologically, with several projects taking place since the 1960s. Prior to AD 900, there is considerable uncertainty about the archaeology in this region, 
and it may well have shared cultural patterns with the Caribbean regions of Nicaragua and Costa Rica. Similar to patterns in central Honduras, the first examples of exchange with Mesoamerica date back to at least $500 \mathrm{BC}$, with early pottery forms showing resemblances to other types found along the Pacific coast toward Guatemala and southern Mexico. Intensity and continuity of these connections, however, remain poorly understood. From 500 BC onward, Usulután-style ceramics also appears in parts of Greater Nicoya, possibly made in local workshops.

In addition to the proposed cultural affiliation to Mesoamerica, the notion of Greater Nicoya also rests on geographical features, perhaps more so than other southern Central American archaeological regions. Chance events, such as volcanic eruptions, had immediate and long-term effects on the development of pre-Hispanic communities in Greater Nicoya. The coastal regions of Nicaragua are defined by the two freshwater lakes and a strip of land separating Lake Nicaragua from the Pacific Ocean by as little as $19 \mathrm{~km}$ at one point. This corridor-like geography was likely a preferred route for down-the-line exchange networks throughout the pre-Hispanic sequence, and excavated settlements in Pacific Nicaragua dating to AD 300 show the movement of materials such as obsidian from other parts of southern Central America, including the central valleys of Honduras and parts of eastern El Salvador.

Possibly tied with migratory movements from Mesoamerica, a series of changes in regional settlement patterns, funerary practices, and material technologies occurs around AD 600 (Hoopes 2005). From this moment on, up to the arrival of the Spanish, pottery finishing shows innovations and changes that have enticed scholars to argue a scenario in which Greater Nicoya took part in a macroregional exchange network, involving the transfer of materials and symbolism. The latter is principally argued through the growing presence of polychrome ceramics in combination with the appearance of new motifs and innovations in finishing techniques, including distinctive whiteslipped ceramics in Pacific Nicaragua and orangeslipped types in northwest Costa Rica. Attesting such migrations, as a direct cause of the changes in material culture, however, has proven elusive (McCafferty 2015). Instead, based on earlier foundational studies, the increased comparative stylistic study and technological sourcing of such pottery is placing greater emphasis on more localized production processes. The current understanding is that pottery production is largely a local process, within and between the northern and southern parts of Greater Nicoya, and appears less significantly linked to exchange beyond Greater Nicoya itself.

Apart from the archaeologically challenging topic of Pacific coastal migration from Mesoamerica into Greater Nicoya, the period from $\mathrm{AD}$ 600 and the increased connections of Greater Nicoya to southern Central America developed into that of a node in the long-distance trade of social valuables produced in parts of Panama and Costa Rica. Although not overwhelming in number, hammered gold disks do show up in various late contexts in the Maya region and the central highlands of Mexico. Metal objects are far from ubiquitous in archaeological contexts of Greater Nicoya, and it is an unresolved question how the itinerant presence of such novel shiny objects would have impacted on societies in Greater Nicoya. Any increase in connections between both regions opens up the question of what the probably quite different human relations to exotic materials could have been, keeping in mind that stylistic comparability need not indicate shared ideas and the new materials and styles would have been perceived as new possibilities and extending ideas on the nature of the wider southern Central American world. Notwithstanding such a wider role for Greater Nicoya, it is one of the archaeological regions in southern Central America where continuity and stability of both population density and organization, as well as practices of pottery production, are most remarkable.

Beyond the immediate Pacific coastal areas of Greater Nicoya, the variable topography, soils, and microclimates make for a more challenging comparison to other parts of this region traditionally considered to skirt Greater Nicoya. The numerous islands in the two lakes principally include Ometepe, Zapatera, and the Solentiname 
archipelago, with considerable indications of human use, but overall there are several hundred smaller ones, all of which feature at least some form of archaeological traces of prehistoric habitational, funerary, or ceremonial activity. Across from Lake Cocibolca, the expansive and loosely defined region of central Nicaragua represents the transitional zone toward the Caribbean lowlands and with intense building of mound-like surface structures, both adapted to local topographies as well as built to form the large ceremonial complex of Aguas Buenas (Geurds and Terpstra 2017). This region, and others connecting Greater Nicoya to central mountainous and Caribbean geographies, harbors the potential to provide further detail to how indigenous communities were enmeshed in relations around natural features such as the mentioned lakes.

\section{Caribbean Nicaragua and Costa Rica}

The Caribbean coastline of Nicaragua and Costa Rica is a region of dense tropical forest cut by numerous rivers. In recent decades, significant deforestation resulted in barely connected pockets of forest in the midst of grasslands used as cattle pasture. Partly as a consequence of the impenetrable character of the region, combined with the high degree of precipitation, the archaeological narrative here is still largely relying on individual site excavations or valley-based surveying, and a detailed understanding of diachronic developments is unavailable. What can be reported is more often than not based on single finds, often the product of salvage interventions, than being the product of long-term archaeological research projects.

Research on the central Caribbean coast of Nicaragua points to the exploitation of marine resources, as evidenced by substantial shell middens documented near the modern town of Bluefields. These sites, lacking in surface domestic architecture, are identified as temporary camps used for fishing, harvesting gastropods, and catching turtles, all possibly for eventual transport and distribution upriver by canoe. Farther inland, the scant archaeological data points to communities relying primarily on agriculture. This appears to have been based on maize, given the abundant presence of grinding stones. This model may in fact not diverge much from the abovementioned subsistence strategies deployed at the Gulf of Fonseca and provide one more example of the attention needed for human adaptations to coastal-inland subsistence strategies.

A second study in Caribbean Nicaragua has documented an example of public ceremonial architecture and the use of stone sculpture (Geurds in press). At the El Gavilán site, just east of the modern town of El Ayote, a site featuring numerous low clay mounds as well as a few considerably higher ones is complemented by two square platforms. These platforms are directly associated to a large cluster of carved and uncarved monolithic sculptures, up to 2 meters tall. This high degree of sculpting activity echoes finds from parts of Caribbean Costa Rica in also being focused on representing human bodies, although it is technologically distinct. The site is situated directly at the confluence of two rivers, placing El Gavilán at an advantageous location for regional gatherings. The monumental layout of the site possibly created a spatial context for conducting public activities involving communities from both up- and downriver. Moreover, the required practices of selection, extraction, transportation, and carving of these monoliths indicate a highly skilled and organized activity. While hypothetical, such a role for establishing and confirming social ties would have been beneficial to the communities in the wider surroundings. A monumental location such as El Gavilán provides rare insight into the conditions needed for the reproduction of shared histories among those participating in its construction, as regional community ties were cemented and maintained in the process. Similar to the studies arguing for river transport for subsistence practices, the location of this ceremonial site also underscores the importance of rivers as expedient ways of transport, highlighting the rivers role as facilitator of contact in southern Central America.

For parts of the lowlands of Caribbean Costa Rica, south of the San Juan River, the data resolution is better. At the relatively early date of approximately $100 \mathrm{BC}$, settlements begin to emerge, typically situated in valleys with alluvial 
deposits, practicing both seed and root crop agriculture. What is remarkable about the material culture of the excavated sites from this period is not so much the domestic or public architecture but the extensive funerary customs, specialized working with lapidary materials (including serpentinite, chalcedony, and other silicate rocks optically similar to jadeite), and a developing practice of fashioning ground stone objects. Overall, the early rise in cultural activity in Caribbean Costa Rica may be related to wider macroregional interaction networks, evidenced again by Olmec style objects (Snarskis 1984). Determining the routes along which such networks may have been established and maintained is a function of defining features in the geography of southern Central America. As such, connections from southern Honduras and perhaps the Gulf of Fonseca, along possibly either side of Lake Nicaragua, into northwest Costa Rica, would have been favored, and from there on forking along the central mountains toward the Caribbean and the Pacific coastal area of Costa Rica.

From $\mathrm{AD} 400$, further noticeable changes occur in Caribbean Costa Rica, with earlier sites showing continued occupation and additional settlements being established in this second half of the first millennium AD. Gold objects become more visible in the archaeological record, and jade-like materials decrease markedly - a process seen more widely in southern Central America in this period. Circular house areas become the norm over the previously seen rectangular footprint, and the use of wide cobblestone paths and pavements is common. Sites such as Guayabo de Turrialba and Nuevo Corinto are prime examples of such forms of housing and also provide indications for chiefly or communal residences. Funerary practices revolve around stone cist structures in a variety of shapes and include the use of flagstones for retaining walls, top cover, and even laying out the tomb floors. A specialized practice of highly decorated and distinctive ceremonial grinding stones is also found from this moment on, as well as various forms of human sculpture, either seated or standing and displaying themes related to warrior identity and trophy heads (Hoopes 2007). Again, it has been argued that these changes in Caribbean
Costa Rica are caused by long-distance contacts, more specifically a change from Mesoamerican trade routes, to strengthening southern connections into the Greater Chiriquí and other parts of Panama and into northwestern Colombia.

\section{Southern Costa Rica and Western Panama}

Parts of southern Costa Rica and western Panama, respectively, known as the Diquís Delta and the province of Chiriquí are collectively referred to as the Greater Chiriquí archaeological region. This concept was originally proposed exclusively for the Pacific coastal slopes of both countries (Haberland 1976) but was expanded to include the Caribbean side of this part of southern Central America as well (Haberland 1984), with the Cordillera de Talamanca as a central geographical separation. While useful as a general frame of reference, the Greater Chiriquí regional definition remains ambiguous on several sides. Uncertainty continues to exist about its northeast boundary, toward the central coastal parts of Costa Rica, as well as regarding the western boundary toward the central Panamanian Greater Coclé region. Additionally, the exact cultural relation of the Caribbean region in the Greater Chiriquí remains under debate. The fragmented geography in this region, consisting of a diverse set of river basins, bay areas, coastal plains, and highlands, may eventually lead to the definition of further cultural subdivisions. While some patterns in ceramic styles and site characteristics referred to as the Aguas Buenas Period are discernible from AD 300 onward, how far back in time this extends is again subject to discussion, with dates as early as 1500 BC also being considered (Corrales 2000), and archaeological patterns varying considerably throughout the region. Integration of communities at the regional level was seemingly limited until AD 800, despite similar ceramic types being spread across the region. In response to this uncertainly, archaeological research has proposed several more localized sequences for the period before AD 800, perhaps indicative of the substantial cultural diversity in the Greater Chiriquí before this date (Corrales 2000).

Cultural developments from AD 300 up to the arrival of the Spaniards are marked by one 
generally recognized period break around AD 600 . From this moment onward, settlements become more complex in their composition and are associated with alluvial plains, and their locations are increasingly co-dependent on access to marine resources (Drolet 1988). In fact, given the varied topography and vegetation, it is assumed that settlements will have had access to multiple food sources, alongside what was being cultivated. Similar to other regions of southern Central America, communities were often composed of both ordinary domestic residences as well as public spaces such as communal plazas and stone monuments, including a unique tradition of fashioning large spheres out of gabbro or limestone, declared UNESCO World Heritage in 2014. Graves were placed on hilltop settings, or in mounds near domestic spaces, with grave goods prominently including distinctive peg-based stone sculptures. Rounded river stones were used for the construction of raised platforms, and served in laying out planned pavements and causeways, comparable to those described for Caribbean Costa Rica. The constructing of mounds was not as ubiquitous as it was in parts of central Nicaragua, with mounds being restricted to certain locations in settlement. Given their increased dimensions and elaboration, they are presumed to have served a more exclusive purpose for the community's leadership and their families. There is ample evidence of maize processing previous to $\mathrm{AD} 600$, but this further intensified after this date (Horn 2006), possibly causally linked to the mentioned marked shifts visible in material culture and community organization. Although gold metallurgy first appears as early as AD 200, an additional defining feature of the period after $\mathrm{AD} 600$ is the expansion of metallurgical production, with especially gold being mined and worked in different parts of the Greater Chiriquí. As different as they will have seen the southern Central American world once they had arrived there, accounts by the Spanish also provide fairly detailed reports on the territorial organization of parts of the Greater Chiriquí region, highlighted by the presence of chiefs and multiple political boundaries in the region, as well as references to the frequency of intercommunity conflict about territory, goods, and captives (Corrales and Badilla 2018).

In the Panamanian province of Chiriquí, there are strong indications of communities gradually developing a certain level of institutional leadership. This is evidenced through specialization in tool production activities in multiple villages, the manufacture of monumental stone objects, including human sculpture. The site of Barriles is one of the more cited examples of the rise in arguing sociopolitical complexity in the Chiriquí. Barriles in fact consists of two related sites and is located in the proximity of the Barú volcano which has a wider set of settlement on its outskirts (Linares and Ranere 1980). Early research at the site yielded a massive four-legged ceremonial grinding stone, several meters in length, and lined with sculpted human heads. Another unique object category is the stone barrel-shaped objects, after which the site is named. Although the cultural sequence at Barriles goes back to at least $\mathrm{AD}$ 300 , the further development of Barriles, and possible other sites of this magnitude, is linked to population growth made possible by an increasing reliance on maize agriculture after AD 600. Whether the advent of intensive maize cultivation is directly causally related to population growth and the emergence of chiefly territorial leadership or if the two developments proceeded in a rather parallel dynamic is debated (Hoopes 2005). Similar to other studied archaeological sites in coastal Pacific Central America, the occupation of Barriles was influenced by a substantial volcanic eruption. This eruption left a clear mark on the stratigraphy, but its dating to around AD 600 is now considered problematic. Accordingly, an active local exchange network was maintained featuring pottery, stone, salt, and staple foods. Overall, from AD 600 onward, the Greater Chiriquí thrived as a region with a diverse settlement pattern, connected to regional trade routes linking Greater Nicoya and central Panama.

\section{Central Panama}

East of the Greater Chiriquí region, central Panama has revealed the temporally deepest archaeological sequence of southern Central America. As discussed above, the first data on human activity 
in central Panama dates back to the Terminal Pleistocene and become more detailed leading up to approximately $500 \mathrm{BC}$, with patterns of human adaptation to the environment enveloping both the Pacific and Caribbean sides of the region. A rich data set attesting the development from hunting and gathering to include fishing and the adoption of agriculture is evidenced. Between $500 \mathrm{BC}$ and $\mathrm{AD}$ 0, settlement locations and agricultural activities shift from foothill areas down to lower alluvial river valleys nearer to the coast. Approximately from this moment onward is when prehistoric activities in this region are referred to as the Greater Coclé tradition (Cooke et al. 2000).

Two parallel developments beginning around AD 200 define the emergence of the Greater Coclé tradition: the development of a number of highly distinctive trichrome and polychrome pottery styles, accompanied by the arrival of metalworking practices having their direct origin in Colombia. The tri- and especially polychromes ceramic types form one of the most ornate and richly decorated pottery styles in southern Central America, perhaps together with the Greater Nicoya polychromes. Coclé-style motifs include supernatural creatures, a range of geometric and organically shaped designs, and various animal depictions as part of other forms of decoration. The practice of trichrome painting on pottery begins around $200 \mathrm{BC}$ and that of polychromes around AD 700 and runs diachronically, through individual styles all the way to the arrival of the Spanish, each style spanning several centuries. Metalwork motifs overlap to some degree with these polychrome styles. How this tradition was organized territorially is the subject of some discussion, with the Pacific coast of Central Panama serving as an oft-cited comparative case study of social hierarchy and chiefly leadership in the Americas. The emergence of such chiefly polities was possibly related to the increasing reliance on maize in the diet of communities in Central Panama. Even though wild fruits and palm nuts are still used, the prominence of maize is shown archaeologically both in starch analyses on grinding stones as well as through stable isotope signals in human bone.
Spanish references frequently mention chiefs and the territory they occupy in Central Panama. These descriptions provide tantalizingly precise observations, many times difficult to verify archaeologically. It is fair to assume that communities featured at least some level of sociopolitical stratification and they were organized based largely on kinship relations. Not every community or settlement will have participated in this political landscape in the same way. In this Pacific coastal environment, the site of Sitio Conte has stood out given the lavish graves dated to $\mathrm{AD}$ 700-900. More recently, the site of El Caño, previously only known for its alignment of carved monoliths, has revealed burials of similar complexity and elaboration (Mayo and Mayo 2013). The sumptuary goods found in these funerary settings are some of the most diverse and impressive known for southern Central America, in spectacular nature rivaling those found in parts of Mesoamerica and the Middle Andes. The leadership authority implicated in such grave finds appears to accord with traditional definitions of chiefly ranked societies, but if this site - identified by its excavators as a necropolis - was in fact an interterritorial burial ground or situated in a single political territory remains unresolved.

The archaeology of Central Panama contributed to comparative analyses on the origins of chiefly leadership, also beyond southern Central America. One argument has recognized the link to individual performance in episodes of conflict between societies and the ability to control and interpret exotic goods, exchanged or personally procured beyond societal horizons. This developed notion on the social and political value of esoteric knowledge forms a widely cited study on elite strategies of wealth and authority (Helms 1979), stressing the importance for chiefly legitimation of having access to the acquisition and interpretation of exotic valuables. A substantial body of research into the development of subsistence strategies in central Panama, however, argues for a more local sociopolitical dynamic whereby technological changes in food procurement and preparation, as well as increasing use of gold ores, are the source of differential access to 
and control over these resources, leading to wealth and display of authority.

\section{Eastern Panama}

Eastern Panama is simultaneously one of the archaeologically least known and most relevant regions to discuss. It is culturally part of what is referred to as the Greater Darien (Cooke 1984), including the northwestern Colombian region around the Gulf of Urabá, the Atrato River, and parts of the Chocó department running along the Pacific coast of Colombia. As mentioned, it has some of the earliest documented pottery traditions in the Americas and also was the avenue through which metalworking made its way north into Central America. Metallurgical knowledge was probably in place in parts of Colombia around at least 500 BC, with examples from central Panama following around $\mathrm{AD} 500$, and then developing into a wide variety of styles, and further technological specializations to fashion ornate gold or tumbaga (copper-gold alloy) objects, including pendants, breastplates, and ear and lip plugs. The modern national boundary now obscures what was the environmental continuity of eastern Panamanian rain forests and those on the other side of the Colombian boundaries in the Chocó region and also along the Caribbean coast of the Gulf of Urabá. As Bray argues (1984), eastern Panama likely constituted a single cultural region from around $\mathrm{AD} 0$ onward, defined by the use of tumbaga pendants featuring a complex iconography and an equally specialized metalworking knowledge. Archaeological data in Greater Darien rely on the excavation of a very limited number of sites, prominently including Momil near the Caribbean coast of northwest Colombia. How the communities were organized in eastern Panama is empirically not well established, but the pattern of chiefdom level societies, as described in Spanish sources, is assumed to come into existence around AD 500. The indigenous societies of Greater Darien were to witness the first Spanish settlement in the mainland Americas in AD 1510.

\section{Summary}

Similar to other regions of the world, the prehistory of southern Central America is defined by cycles of transformation as well as a marked stability in how its societies defined themselves and related to others. Regional containers such as southern Central America and all the subareas described above are archaeologically useful heuristic devices, but not very informative on social realities and how human action shaped that what is now called the prehistory of southern Central America. Archaeological evidence indicates that communities roamed, changed, and settled the diverse landscapes of this American isthmus and in the process created a long-term dynamic of adaptation and mobility. Such patterned action is, in turn, recognized archaeologically, albeit with different resolutions across Central America. What marks this area region from a global archaeology standpoint are two main points: the extraordinary position in the midst of two continental landmasses and because of this, the unique role played by southern Central America in the initial human colonization of the Americas, perhaps globally late but with great velocity, and second, the remarkable stability of social life (as seen also in genetic and linguistic data) in the midst of forming part of macroregional exchange networks that saw jadeite, gold, and copper objects, among various other forms, spread through and across the region.

Steadily, archaeology is beginning to reveal that different forms of cultural expression from the earliest periods of human presence down to the advent of European colonization revolved around the indigenous communities' concerns of how to successfully negotiate regional cultural, linguistic, and social differences as well as the geographical character of the area. Such concerns were in part surely unconscious but in part also active decisions, as shown, for example, in the spread of certain pottery styles. All this resulted in communities, with a range of densities and forms of organization that existed contemporaneously and with extraordinary stability, until the sixteenth century.

After Christopher Columbus explored the Caribbean coasts of southern Central America 
during his fourth voyage in 1502 , the period of Spanish incursions into Central America is a history of frequent violence and massive death. These events effectively ended the prehistoric period, even though for the vast majority of elements that defined indigenous life in southern Central America no historical writings would ever become available. Notwithstanding the cataclysmic changes occurring in the sixteenth century, indigenous settlement continued in certain areas until well after colonial administration of the region had begun. Evidence from sites such as Paso Real in the foothills of the Diquís region of Costa Rica, for example, shows European glazed ceramic wares and glass beads to be present in indigenous graves. However fragile, such continuity seems to mostly appear, perhaps predictably, in areas of very low population density and poor infrastructure.

\section{Cross-References}

- Archaeology of Monte Verde

- Central America: Historical Archaeology of Early Colonial Urbanism

- Classic Maya Collapse: An Alternative View

Doyce, R.

- Maize: Origins and Development

- Mesoamerica in the Classical Period

- Mesoamerica's Archaic Period

- Metallurgy

- Olmec: Geography and Culture

$\checkmark$ Paleoindians

- Peopling of the Americas

- Reichel-Dolmatoff, Gerardo

- Willey, Gordon Randolph

\section{References}

Andrews, E.W. 1976. The archaeology of Quelepa, El Salvador. New Orleans: Middle American Research Institute, Tulane University.

Barnett, W., and J.W. Hoopes. 1995. The emergence of pottery: Technology and innovation in ancient societies. Washington, DC: Smithsonian Institution Press.

Baudez, C.F. 1970. Central America. New York: Barrie \& Jenkins.
Baudez, C.F. 1976. Llanura costera del Golfo de Fonseca, Honduras. Vínculos 2 (1): 15-23.

Bray, W.M. 1984. Across the Darién Gap: A Colombian view of isthmian archaeology. In The archaeology of lower Central America, ed. F.W. Lange and D.Z. Stone, 305-338. Albuquerque: University of New Mexico Press.

Coates, A.G., and J.A. Obando. 1996. The geologic evolution of the central American isthmus. In Evolution and environment in tropical America, ed. J.B.C. Jackson, A.F. Budd, and A.G. Coates, 21-56. Chicago: University of Chicago Press.

Cooke, R.G. 1984. Archaeological research in central and eastern Panama: A review of some problems. In The archaeology of lower Central America, ed. F.W. Lange and D.Z. Stone, 263-302. Albuquerque: University of New Mexico Press.

Cooke, R.G. 2005. Prehistory of native Americans on the Central American land bridge: Colonization, dispersal, and divergence. Journal of Archaeological Research 13 (2): 129-187.

Cooke, R.G., A. Ranere, G. Pearson, and R. Dickau. 2013. Radiocarbon chronology of early human settlement on the Isthmus of Panama (13,000-7000 BP) with comments on cultural affinities, environments, subsistence, and technological change. Quaternary International 301: 3-22.

Corrales, F.C. 2000. An evaluation of long term cultural change in southern Central America: The ceramic record of the Diquís archaeological subregion, southern Costa Rica. Unpublished PhD dissertation, University of Kansas.

Corrales, F.C., and A. Badilla. 2018. Sociedades jerárquicas tardías en el delta del Diquís, sureste de Costa Rica. Cuadernos de Antropología 28 (2): 1-23.

Dillehay, T.D., C. Ocampo, J. Saavedra, A. Oliveira Sawakuchi, R.M. Vega, M. Pino, M.B. Collins, L. Scott Cummings, I. Arregui, X.S. Villagran, G.A. Hartmann, M. Mella, A. González, and G. Dix. 2015. New archaeological evidence for an early human presence at Monte Verde, Chile. PLoS One 10 (11): e0141923.

Drolet, R. 1988. Emergence and intensification of complex societies in Pacific Southern Costa Rica. In Archaeology and art in Costa Rican prehistory, ed. F.W. Lange, 163-188. Boulder: University of Colorado Press.

Fonseca, O. 1994. El concepto de Área de Tradición Chibchoide y su pertinencia para entender Gran Nicoya. Vínculos 18: 209-228.

Geurds, A. in press. Monumental stone sculpture in central Nicaragua. In Toward an Archaeology of "Greater" Central America, ed. C. McEwan, B. Cockrell, and J.W. Hoopes. Washington, DC: Dumbarton Oaks.

Geurds, A., and D. Terpstra. 2017. Circular reasoning in mound building? Large- scale planned construction patterns at the Aguas Buenas site (A.D. 400-1525). In War \& Peace: Conflict and Resolution in Archaeology, Proceedings of the 45th annual Chacmool archaeology 
conference, ed. A.K. Benfer, 47-59. Calgary: University of Calgary.

Haberland, W. 1976. Gran Chiriqui. Vinculos 2: 115-121.

Haberland, W. 1984. The archaeology of greater Chiriquí. In The archaeology of lower Central America, ed. F.W. Lange and D.Z. Stone, 233-262. Albuquerque: University of New Mexico.

Hartman, C.V. 1901. Archaeological researches in Costa Rica. Stockholm: Ivan Hægg Strömes Boktryckeri.

Hartman, C. V. 1907. Archeological Researches on the Pacific Coast of Costa Rica. Pittsburgh: Carnegie Institute.

Healy, P.F. 1980. Archaeology of the Rivas region, Nicaragua. Waterloo: Wilfred Laurier Press.

Healy, P.F. 1984. The archaeology of Honduras. In The archaeology of lower Central America, ed. F.W. Lange and D.Z. Stone, 113-164. Albuquerque: University of New Mexico Press.

Helms, M.W. 1979. Ancient Panama: Chiefs in search of power. Austin: University of Texas Press.

Hoopes, J.W. 1995. Interaction in hunting and gathering societies as a context for the emergence of pottery in the Central American isthmus. In The emergence of pottery: Technology and innovation in ancient societies, ed. J.W. Hoopes, 185-198. Washington, DC: Smithsonian Institution.

Hoopes, J.W. 2005. The emergence of social complexity in the Chibchan world of southern Central America and northern Colombia, AD 300-600. Journal of Archaeological Research 13 (1): 1-47.

Hoopes, J.W. 2007. Sorcery and the taking of trophy heads in ancient Costa Rica. In The taking and displaying of human body parts as trophies by Amerindians, ed. R.J. Chacon and D.H. Dye, 444-480. Boston: Springer.

Hoopes, J.W., and O.M. Fonseca. 2003. Goldwork and Chibchan identity: Endogenous change and diffuse unity in the Isthmo-Colombian area. In Gold and power in ancient Costa Rica, Panama, and Colombia, ed. J.W. Hoopes, O.M. Fonseca, and J. Quilter, 49-89. Washington, DC: Dumbarton Oaks.

Horn, S.P. 2006. Pre-Columbian maize agriculture in Costa Rica: Pollen and other evidence from lake and other sediments in. In Histories of maize in Mesoamerica: Multidisciplinary approaches, ed. J. Staller, R. Tykot, and B. Benz, 367-380. London: Elsevier.

Joyce, R.A. 2004. Unintended consequences? Monumentality as a novel experience in formative Mesoamerica. Journal of Archaeological Method and Theory 11 (1): 5-29.

Joyce, R.A. 2017. Painted Pottery of Honduras: Object lives and itineraries. In The early Americas: History and culture, The early Americas: History and culture 6. Leiden: Brill Publishers.

Kirchhoff, P. 1943. Mesoamérica. Acta Americana 1 (1): 92-107.

Lange, F.W. 1984. The greater Nicoya archaeological subarea. In The archaeology of lower Central America, ed. F.W. Lange and D.Z. Stone, 165-194. Albuquerque: University of New Mexico Press.
Linares, O.F. 1979. What is lower central American archaeology? Annual Review of Anthropology 8 (1): 21-43.

Linares, O.F., and A.J. Ranere, eds. 1980. Adaptive radiations in prehistoric Panama. Boston: Peabody Museum of Archaeology and Ethnology, Harvard University.

Longyear, J.M., III. 1966. Archaeological survey of El Salvador. In Handbook of middle American indians, volume 4: Archaeological frontiers and external connections, ed. R. Wauchope, 132-156. Austin: University of Texas Press.

Mayo, J., and C. Mayo. 2013. The discovery of an elite cemetery at El Caño: Traces of a mortuary pattern in Río Grande valley, Coclé, Panama. Arqueología Iberoamericana 20: 3-27.

McCafferty, G. 2015. The Mexican legacy in Nicaragua, or problems when data behave badly. Archaeological Papers of the American Anthropological Association 25: 110-118.

McCafferty, G., F.E. Amador, S. Salgado, and C.L. Dennett. 2012. Archaeology on Mesoamerica's southern frontier. In The Oxford handbook of Mesoamerican archaeology, ed. D.L. Nichols and C.A. Pool, 83-105. Oxford: University of Oxford Press.

Piperno, D.R., M.B. Bush, and P.A. Colinvaux. 1991. Paleoecological perspectives on human adaptation in Central Panama. II the Holocene. Geoarchaeology 6 (3): 227-250.

Sampeck, K. 2014. Ancient Quelepa, colonial San Miguel: Shifting cultural frontiers and rogue colonialism in eastern El Salvador. In The Maya and their central American neighbors, ed. G. Braswell, 76-102. London: Routledge.

Schortman, E., and P. Urban. 2011. Power, memory, and prehistory: Constructing and erasing political landscapes in the Naco Valley, northwestern Honduras. American Anthropologist 113 (1): 5-21.

Sheets, P.D. 1992. The pervasive pejorative in Intermediate Area studies. In Wealth and Hierarchy in the intermediate Area, ed. F.W. Lange, 15-41. Washington, DC: Dumbarton Oaks.

Sheets, P.D., and B.R. McKee, eds. 1994. Archaeology, volcanism, and remote sensing in the Arenal region, Costa Rica. Austin: University of Texas Press.

Snarskis, M.J. 1984. Central America: The lower Caribbean. In The archaeology of lower Central America, ed. F.W. Lange and D.Z. Stone, 195-232. Albuquerque: University of New Mexico Press.

Stone, D.Z. 1972. Pre-Columbian man finds Central America: The archaeological bridge. Washington, DC: Peabody Museum of Archaeology.

Willey, G.R. 1955. The prehistoric civilizations of nuclear America. American Anthropologist 57 (3): 517-593.

\section{Further Reading}

Braswell, G.E., S. Salgado González, L.A. Fletcher, and M.D. Glascock. 2002. La antigua Nicaragua: la periferia sudeste de Mesoamérica y la región maya: 
interacción interregional (1-1522 d.C.). Mayab 15: 19-39.

Carmack, R.M., and S. Salgado González. 2006. A worldsystems perspective on the archaeology and ethnohistory of the Mesoamerican/lower Central American border. Ancient Mesoamerica 17 (2): 219-229.

Constenla Umaña, A. 1995. Sobre el estudio diacrónico de las lenguas chibchenses y su contribución al conocimiento del pasado de sus hablantes. Boletín del Museo del Oro 38/39: 13-56.

Cooke, R.A. 1998. Human settlement of Central America and northernmost South America (14,000-8000 BP). Quaternary International 49: 177-190.

Cooke, R.G., L.A. Sánchez Herrera, and K. Udagawa. 2000. Contextualized goldwork from 'Gran Coclé', Panama: An update based on recent excavations and new radiocarbon dates for associated pottery styles. In Precolumbian gold: Technology, style, and innovation, ed. C. McEwan, 154-176. Chicago: Fitzroy Dearborn Publishers.

Cooke, R.G., L.A. Sánchez Herrera, D.R. Carvajal, J. Griggs, and I.A. Isaza. 2003. Los pueblos indígenas de Panamá durante el siglo XVI: transformaciones sociales y culturales desde una perspectiva arqueológica y paleoecológica. Mesoamérica 45: 1-34.

Corrales, F. 2000. An evaluation of long-term cultural change in southern Central America: The ceramic record of the Diquís archaeological subregion, Costa Rica, Unpublished $\mathrm{PhD}$ dissertation, University of Kansas, Lawrence.

Creamer, W. 1987. Mesoamerica as a concept: An archaeological view from Central America. Latin American Research Review 22 (1): 35-62.

Dennett, C.L. 2016. The ceramic economy of preColumbian Pacific Nicaragua (AD 1-1250). Unpublished $\mathrm{PhD}$ dissertation, University of Calgary.

Donner, N.R., A. Arteaga, A. Geurds, and K. van Dijk. 2018. Preliminary characterization of archaeological sites in the Mayales River subbasin, Chontales Department, Nicaragua. Cuadernos de Antropologia 28: $1-26$.

Gónzalez Fernández, V., ed. 2012. Arqueología en el Área Intermedia. Bogotá: Instituto Colombiano de Antropología e Historia.

Healy, P.F. 1978. Excavations at Rio Claro, Northeast Honduras: Preliminary report. Journal of Field Archaeology 5 (1): 15-28.

Holmberg, K. 2009. Nature, material, culture, and the volcano: The archaeology of the volcán Barú in highland Chiriquí, Panamá. Unpublished PhD dissertation, Columbia University.

Hoopes, J.W. 1994. Ford revisited: A critical review of the chronology and relationships of the earliest ceramic complexes in the New World, 6000-1500 B.C. Journal of World Prehistory 8 (1): 1-50.

Lange, F.W. 1979. Theoretical and descriptive aspects of frontier studies. Latin American Research Review 14 (1): 221-227.
Lange, F.W. 1984. Cultural geography of pre-Columbian lower Central America. In The archaeology of lower Central America, ed. F.W. Lange and D.Z. Stone, 34-60. Albuquerque: University of New Mexico Press.

Lange, F.W., V. Canouts, and S. Salgado. 1992. The greater Nicoya ceramic database: Development and application. In Chemical characterization of ceramic pastes in archaeology, Monographs in world archaeology 7, ed. H. Neff, 171-187. Madison: Prehistory Press.

Lothrop, S.K. 1942. Coclé: An archaeological study of Central Panama. Boston: Peabody Museum of Archaeology and Ethnology, Harvard University.

Luke, C., and R.H. Tykot. 2007. Celebrating place through luxury craft production: Travesía and Ulua style marble vases. Ancient Mesoamerica 18 (2): 315-328.

Magnus, R.W. 1978. The prehistoric and modern subsistence patterns of the Atlantic coast of Nicaragua: A comparison. In Prehistoric coastal adaptations: The economy and ecology of maritime coastal middle America, ed. B.L. Stark and B. Voorhies, 61-80. New York: Academic Press.

Newson, L.A. 1987. Indian survival in colonial Nicaragua. Norman: University of Oklahoma Press.

Norweb, A. 1964. Ceramic stratigraphy in southwestern Nicaragua. In Proceedings and transactions of the 35th international congress of Americanists, vol. 1, Mexico City 551-561.

Palumbo, S.D. 2009. The development of complex society in the Volcán Barú region of western Panama. Unpublished $\mathrm{PhD}$ dissertation, University of Pittsburgh.

Ranere, A.J., D.R. Piperno, I. Holst, R. Dickau, and J. Iriarte. 2009. The cultural and chronological context of early Holocene maize and squash domestication in the Central Balsas River Valley, Mexico. Proceedings of the National Academy of Sciences 106 (13): 5014-5018.

Reich, D., N. Patterson, D. Campbell, A. Tandon, S. Mazieres, N. Ray, M.V. Parra, W. Rojas, C. Duque, N. Mesa, L.F. García, O. Triana, S. Blair, A. Maestre, J.C. Dib, C.M. Bravi, G. Bailliet, D. Corach, T. Hünemeier, M.C. Bortolin, F.M. Salzano, M.L. Petzl-Erler, V. Acuña-Alonzo, C. Aguilar-Salinas, S. Canizales-Quinteros, T. Tusié-Luna, L. Riba, M. Rodríguez-Cruz, M. López-Alarcón, R. CoralVázquez, T. Canto-Cetina, I. Silva-Zolezzi, J.C. Fernandez-López, A.V. Contreras, G. JiménezSánchez, M.J. Gómez-Vázquez, J. Molina, A. Carracedo, A. Salas, C. Gallo, G. Poletti, D.B. Witonsky, G. Alkorta-Aranburu, R. Sukernik, L. Osipova, S.A. Fedorova, R. Vásquez, M. Villena, C. Moreau, R. Barrantes, D. Pauls, L. Excoffier, G. Bedoya, F. Rothhammer, J.M. Dugoujon, G. Larrouy, W. Klitz, D. Labuda, J. Kidd, K. Kidd, A. Di Rienzo, N.B. Freimer, A.L. Price, and A. RuízLinares. 2012. Reconstructing native American population history. Nature 488: 370-374.

Reindel, M., P. Fux, and F. Fecher. 2017. Guadalupe, Honduras. Kulturelle Interaktion und vorspanische 
Siedlungsgeschichte im Nordosten von Honduras. Die Arbeiten der Jahre 2016 und 2017. E-Forschungsberichte 2: 89-92.

Snarskis, M.J. 1992. Wealth and hierarchy in the archaeology of eastern and Central Costa Rica. In Wealth and hierarchy in the intermediate area, ed. F.W. Lange, 141-164. Washington, DC: Dumbarton Oaks.
Steinbrenner, L.L. 2010. Potting traditions and cultural continuity in Pacific Nicaragua, AD 800-1350. Unpublished $\mathrm{PhD}$ dissertation, University of Calgary.

Van Broekhoven, L.N.K. 2002. Conquistando lo invencible: fuentes históricas sobre las culturas indigenas de la región central de Nicaragua, CNWS Publications 31. Leiden: CNWS Publications. 